\title{
TRAUMA AND MATURATION IN WOMEN'S WAR NARRATIVES: THE EYE OF THE MIRROR AND CRACKING INDIA
}

\author{
KAMran RASTEgar
}

6 ด

\begin{abstract}
A comparative study of Liana Badr's The Eye of the Mirror and Bapsi Sidhwa's Cracking India shows that these two novels present intriguingly similar feminist frameworks through which the traumas of war and communal violence may be addressed. They do so by erasing the distinction between literary work and critical social history, producing what we may term counterhistories of the Lebanese Civil War and the Partition of India. In both of these novels, a girl upon the verge of sexual maturation sees the eruption of violence in the society around her to be fundamentally analogous to the inherent violence that accompanies the new social role she is being thrust into as a womanthis is achieved through the presentation of the narrative from the character's "naïve perspective." These and the other literary strategies in the texts destabilize what is anticipated in the predominant war narrative, by linking the political, often nationalist violence of these stories to the intimate violence sustaining the structures of patriarchal social institutions within which the characters exist.
\end{abstract}

$\mathrm{T}$ he predominant narratives of war largely aim to rationalize violence. The closure of trauma often inherent in these narratives of war, be they historical texts or popularized "war stories," attempts to rationalize the violence that characterizes the experience of war. ${ }^{1}$ These narrative tac- 
tics, whether they assume objectivity, as dominant historical texts claim, or promote a specific ideology, as for example many popular war films do, intend to bring an acceptable resolution to the often irresolute trauma resulting from the violence. These narratives, in searching for simple resolutions, are most often founded upon inflexible representations of gender roles or identities. Thus, largely authored within imaginations centered in masculine tropes, women are most often marginalized in the narrative of war and communal conflict.

Both Liana Badr's 'Ayn al-Mir'a (The Eye of the Mirror) (1991) and Bapsi Sidhwa's Cracking India (also published as Ice Candy Man) present intriguing feminist frameworks through which the traumas of war and communal violence may be addressed. They do so by erasing the distinction between literary work and critical social history, producing what we may term "counterhistories." 2 This article will examine how these two texts, by representing the experiences of women, can be read as counterhistories to predominant historical representations that attempt to justify the violence of war through the reification of largely masculine tropes of the war narrative. ${ }^{3}$ While such counterhistories may be produced by the application of various narrative techniques or approaches, this analysis will focus specifically on how the use of a "naïve perspective" in each of these texts serves to reorient the representation of the traumatic and still largely unresolved histories they discuss. The Eye of the Mirror recounts the long siege of a Palestinian refugee camp during the early years of the Lebanese Civil War, through the eyes of a refugee girl, and Cracking India follows the experiences of a middle-class Parsee girl and those in her household during the events of India's Partition. Specifically, the construction of each novel around the maturing protagonist-a nearly-adolescent Aisha in The Eye of the Mirror, and a somewhat younger Lenny in Cracking India-places this character's naïve, yet maturing, perspective on the events of communal violence and war that upend conventional conceptions of these events. This naïve perspective, derived from the relative immaturity of the characters, also generates a developmental structure for the stories, as each character matures over the course of the narrative. ${ }^{4}$

In each of these novels, a girl upon the verge of sexual maturation sees the eruption of violence in the society around her to be fundamentally analogous to the inherent violence accompanying the new social 
role she is being thrust into as a woman. What this and other strategies in these texts do is destabilize what is anticipated in the predominant war narrative, by linking the political, often nationalist violence of these stories to the intimate violence sustaining the structures of patriarchal social institutions within which the characters exist. Narratives that refuse to accept the limitations in gender roles and identities that occur in predominant war stories thus may provide a unique perspective on the complex and often-changing social terrain of wartime societies-in particular in the context of civil or sectarian violence. As miriam cooke has stated, "What women experience in war repeats in stereo the daily experience of violence that has become ordinary" (2004:41). This perspective on masculinized violence allows texts with a critical perspective on gender roles and identities to interrogate the dominant historical narratives emerging from war.

\section{THE PARTITIONS OF INDIA AND PALESTINE}

The Partition of India and the foundation of the nations of India and Pakistan. The Lebanese Civil War and its evocation of the memories of the Palestinian Nakba of 1948. A series of events in a postcolonial history of communal violence with far-reaching consequences. ${ }^{5} \mathrm{~A}$ history now rationalized in the cycle of India-Pakistan wars and the persistence of the question of Palestine. These lists are not exhaustive nor have their echoes subsided. They comprise a litany made banal by the narrative of "ancient hatreds" that still permeates prevalent discourses on these and other contemporary conflicts. This rationalizing narrative obfuscates other histories that may present these events within the moral rhetoric of the present, thus making them immediate, their histories vital. Partitions, more or less a twentieth-century political innovation, once were perceived as being exemplary of judicious diplomacy based on the "inevitable" nature of ethnic or religious strife and thus have been the internationally recognized goal of various political movements of the postcolonial period. ${ }^{6}$ Two of the most intractable examples must be the partitions of India and of Palestine, initiating traumatic events that, while fundamentally of different geopolitical circumstances, invite comparison as well. In particular, what was fundamental to each partition plan was the intention to codify national identity on the 
basis of religious difference. The aftermath of the partition of Palestine extends to and beyond the Lebanese Civil War, with the complex and changing alliances between factions during the war, often involving Palestinian refugees in Lebanon, serving to belie the simple view of the war's precipitation by generically "Christian" and "Muslim" sides. This simplistic view also elides the role of Israel, in the development of these communal tensions and in the escalation of violence that was a consequence of its 1982 invasion of Lebanon. The legacy of the Partition of India is echoed in the continuing Hindu, Muslim, and Sikh tensions within India, in the nuclear arms race between India and Pakistan, and in the unresolved fate of a Kashmir torn by oppression and violence.

While these histories are in some ways comparable, they are distinguished by fundamental differences. However, their differences largely become problematic in the context of the prevalent political histories of these areas in their postcolonial periods, while comparisons between them are validated most clearly in an investigation of the social experiences that coincide with the consequences of these political dimensions. These investigations would focus on the repercussions of experiences such as mass expulsions, the rape of women, and massacres of unarmed civilians, and behind all of this would loom the façade of the hardening of identity differences not considered to be essential before the conflict. These experiences betray a counterhistory to the discourse of ancient hatreds, a discourse that makes abstract the apocalyptic nature of these stories for the victims just as they dispel the causal elements of the event into a vacuum of petrified history. Furthermore, when predominant historical analyses rise above this mode of "objective" narration, they rarely if ever break with the discourse of political history and cross over into the realm of what may be termed critical history, following what Dominick LaCapra has described as historical work that "mitigates the stark dichotomy between history and metahistory, if by the latter one means critical and self-critical theory bearing on the practice of history itself" (1995:803). Menon and Bhasin identify the lack of this intention as the foremost weakness with existing histories on the Partition of India.

The abundance of political histories on Partition is almost equaled by the paucity of social histories of it. This is a curious and somewhat inexplicable circumstance: how is it that an event of such tremendous 
societal impact and importance has been passed over in silence by the other social sciences? (1998:6-7)

Menon and Bhasin suggest an answer to this question-the construction of social narratives that can counter the totalizing discourse of the available political histories. Literature, particularly literature produced by those experiencing such events first hand, can fill the representational gap that political histories of such an event leave open. ${ }^{7}$ As contemporary literary and historiological inquiry problematizes the notion of "objective" histories, "fictional" representation has begun to be accepted as fulfilling a specific role in the larger question of what history is and can be. ${ }^{8}$ Thus, the often-stilted invocation of an official history to serve the needs of the state may be challenged by various kinds of literary productions, including autobiographies, ficto-biographies, or oral histories. Badr and Sidhwa's novels fit within this kind of writing-they are semifictional, semibiographical. Indeed, Sidhwa articulates her aim at writing Cracking India as prescriptive, as "my intention was to write about Partition because very little had been written about it. There are certain images from my past which have always haunted me....Although I was very young then, I saw chance killings, fires, dead bodies. These are images which have stayed with me....This hostility needs to be dealt with" (Sidhwa and Singh 1998:202). Liana Badr also has stated that The Eye of the Mirror is a result of her own experiences as a Palestinian living in Lebanon during the war.'

\section{CRACKING INDIA: THE NAIIVE PERSPECTIVE AND THE DERATIONALIZATION OF VIOLENCE}

As a first-person narrative, Cracking India effectively juxtaposes the maturation of its young protagonist, Lenny, with the escalation in violence as the struggle for Indian independence is climaxing and as the prospect of a partition of India is growing more real. The loss of innocence attributed to adolescence, as traced through Lenny's maturation in this tumultuous period, becomes a metaphor for the loss of the surrounding community's innocence as political disaster looms in the last days of British colonialism. As Ambreen Hai has noted, through Lenny's eyes, the narrative "locates itself at the nexus of a number of intersect- 
ing contemporary concerns: gender, violence, nationalism, cross-class representation, and ethnicity" (2000:410). Yet, what is particular to her perspective is precisely Lenny's ignorance of the function and effect of these categories. The naïve perspective allows Lenny to ask questions that would otherwise be unacceptable and to interrogate the foundations of the communitarian violence around her in ways clearly unavailable to her older family members. As a girl, however, she comes to understand that the foundations of violence in her surroundings are largely gendered and that the experience of this violence is differentiated along gender lines. The naïve perspective also leads Lenny to understand the differentiation of religious identity to be largely performative, an artifice. As the violence surrounding Partition spreads with incomprehensible speed across her known world, it is Lenny who can most easily see the changing faces of each character-and in particular the Ice Candy Man-as gestural and performative undertakings, not as reflecting an essential difference based on religious identity.

Cracking India follows the perspective of Lenny in the period before Partition, as part of a middle-class Parsee family in Lahore, in a multireligious household. Her parents are typically bourgeois and distant and leave the daily raising of Lenny to her nanny, Ayah, a Hindu woman from Punjab. Other servants in the house are Muslim, and they are familiar with a local young man called "Ice Candy Man," as he sometimes sells ice cream. As the violence of Partition rises, Ice Candy Man, who has long been a suitor of the beautiful Ayah, turns to political and religious sermonizing, taking on the role of a minor nationalist leader in their area. He eventually leads a mob to the house, and Ayah is taken away. Later it becomes known that he has resorted to pimping Ayah as a "dancer" in the red-light district of Lahore. Lenny's godmother, a stern and powerful woman, extricates Ayah from this situation. Ice Candy Man is dejected and disappears after crossing the border into India.

Lenny first becomes conscious of the performative nature of religious identity when the Ice Candy Man, after quoting one of his nationalist heroes, asks Ayah why she does not wear traditional Punjabi clothes. Ayah's rationale is one of economy, that wearing Punjabi shalwar-kamize would entitle her to a salary of half of what she earns by wearing a sari. However, the effect on Lenny is important: "Though 
it has never struck me as strange before-I'm so accustomed to Ayah only in a sari-I see the logic of this question and wonder about it" (29). The naïve perspective allows Lenny to realize the exact moment when the performative nature of identity becomes "logical," when failing to assume a normative stance can be considered "strange." That the discussion arises from Ice Candy Man's referencing of nationalist rhetorics further brings the identitarian logic of his question into juxtaposition with nationalist ideology. Lenny finds this rhetoric tiresome: "Mother, Father and their friends are always saying: Gandhi said this, Nehru said that. Gandhi did this. Jinnah did that. What's the point of talking so much about people we don't know?" (29); nonetheless, she is all too aware of their influence, even on her parents. The simple question of why these unfamiliar people can wield such influence on the intimate relations of family members as well as those of their servants cuts through the seemingly adult assumption that nationalist rhetoric is to be simply mimicked as the Ice Candy Man does.

This juxtaposition recurs, when Lenny first realizes the possibility of Partition. While Cousin, Lenny's male first cousin and closest playmate, is dismissive of these fears-"Rubbish,... no one's going to break India. It's not made of glass!"-Ayah is more sober, admitting that they may "crack India with a long, long canal" (93). As she lists the names of the nationalist leaders, names that are "names I hear," Lenny realizes she has "become aware of religious differences" (93). This sudden transformation is linked directly to the escalation of nationalist rhetorics and the political struggle that have led to considerations of a partition. "One day everyone is themselves-and the next day they are Hindu, Muslim, Sikh, Christian. People shrink, dwindling into symbols. Ayah is no longer just my all-encompassing Ayah-she is also a token. A Hindu. Carried away by a renewed devotional fervor she expends a small fortune on joss-sticks, flowers and sweets on the gods and goddesses in the temples" (93).

The renewal of devotional fervor affects most of the people around Lenny, although as Parsees, her family has little interest in entering this communal political contest between Hindus, Muslims, and Sikhs. Again, the naïve perspective leads Lenny to presume a state of being before these identity distinctions can be natural, where "everyone is themselves." The juxtaposition of the "names I hear" with the transfor- 
mation of people into simple symbols links nationalist rhetoric to the shifts in the value of religious identity that she senses around her. To Lenny, the artifice of religious identity is brittle, even gaudy, and largely incomprehensible. As Ayah re-Hindu-izes herself with joss-sticks and sweets, the Muslim servants Imam Din and Yousaf both seem equally absurd when they suddenly begin to prepare for the Friday prayers by "diligently scrubbing between their toes." Furthermore, a hierarchy eventually emerges, embedding people into their religious identities on a valuative scale hitherto unperceived by Lenny. Thus the Parsees, Lenny finds, are "reduced to irrelevant nomenclatures" between the Muslim and Hindu communities that are mobilized by nationalist rhetoric. This leads Lenny to confront the most fundamental of questions: "What is God?" (94).

This is not to say that for Lenny religious identity appears in any sense meaningless. The gathering of the Parsee community, which she and her family attend, makes painfully clear the very practical and even more so political nature of religious posturing within this dynamic social context. The Parsees, more than the other religious communities, have to arrive consciously at a consensus regarding how to present themselves to the larger society. The danger of an ill-considered decision is painfully clear-a return to religious persecution. As the community most historically attuned to these dangers, the Parsees' concerns are the most self-conscious of the various religious communities, all of whom have found their identities to be tools in larger political battles, the repercussions of which they are uncertain. Lenny's child's-eye perspective continually problematizes the emergence of these divisions and the personal traits resulting from them; are they indeed new or an aspect of society she had earlier been ignorant of? The absurdity of these distinctions is sensible in the naïve perspective of a child, whereas the adults, implicated as they are in the nationalist rhetoric of the time, continually rationalize these emerging fault-lines and therefore prepare the scene for the justification of the violence to come.

Lenny's growing awareness of the implications of religious difference are intertwined with her "learning" of the implications of gender difference. She learns of the "complex rites" that balance Ayah's relations with her numerous male admirers. Bored as she is by the dances between Ayah and her suitors (most notably the Ice Candy Man and his "big 
toe's romantic impulse" [19]), she begins to internalize conceptions of gender difference through her interactions with Cousin. He, always her teacher, shows her his hernia scar and convinces her to hold his genitals. Shortly after, he smothers her with a pillow and convinces her to touch an electric outlet, actions that align the recognition of gender difference and sexuality with the violence defining these roles. These games, while not horrific to Lenny, define gender in a context complicated by this violence. Her process of "learning" these roles makes visible what, in an adult context, is invisible.

Over the course of Cracking India, Lenny's naïve perspective slowly changes, as she matures and begins to comprehend more and more of the dark logic of the world of the grown-ups. An attack by a Muslim mob (led by the Ice Candy Man) on her street presents the breaking point of this perspective, where she herself unwittingly betrays Ayah because she does not understand the danger at hand. Imam Din, aware of the mob's intentions, blasphemes by taking a false oath, stating that Ayah has left; to him, the limits of devotion are clear, and he is willing to betray his religious credibility to save Ayah. Although Lenny's intentions are unexplained, the moment of her betrayal of Ayah is the continuity of her desire to believe in the beneficence of the Ice Candy Man, to imagine him and his "love" for Ayah to be good. Her naïve perspective precludes an ability to anticipate his later actions, whereas for the adults gathered outside the house, the consequences of the mob's actions are clear, almost inevitable. This betrayal, then, is also a moment of realization that her innocence, which until now had protected her from the violence and hatred around her, is flawed. Her continuing belief in that state when "everybody is themselves" (93) leads to a tragic miscalculation of the potential for violence inherent in those people, even her friends and family members.

Rather than seek to displace the cause for the violence against women that characterized the Partition, Ice Candy Man familiarizes the culprit of Ayah's kidnapping, forced conversion, and degradation as a dancing girl. In this last segment, the narrative does complicate the assumed gendered rationales that might have painted the Ice Candy Man as having been transformed into a monster, unrecognizable and despicable. Instead, the Ice Candy Man is rendered a pathetic character, reciting poetry about romantic love even as he profits financially from 
Ayah's beauty. Previously charming and persuasive, now he cannot even begin to explain himself in a way that would be comprehensible to Lenny. Furthermore, the narrative refuses to discount women's modes of agency, by having Lenny's godmother confront Ice Candy Man and eventually free Ayah from his control. In the face of this power, Ice Candy Man can do no more than hold a pathetic vigil for Ayah near the Recovered Women's Camp, where she has sought refuge. His poetry is the poetry of unrequited love under the prohibiting eye of society, the irony of which strikes Lenny, undermining her ability to identify at all with the masculinity-edifying romantic love tradition. ${ }^{10}$

This pathos-inflected love is replicated in Cousin's repeated requests that Lenny marry him. She, once his student and all but under his sway, now finds little interest in him. She has come to understand the power of her desires and to be wary of the myths of romantic love that, she has realized, would justify even the crimes of Ice Candy Man. Cousin cannot understand and has come to identify with Ice Candy Man's actions, describing the dancing girls in the Kotha in fantastic terms. To him, the Kothas, in the area of town where prostitution and entertainment are confined, are "the cultural pulse of the city," where "poets are inspired...their songs sung by the girls" (267). All the while, he warns Lenny that if she were to go there after dark she would certainly be raped. His vision of poetic inspiration, indeed of "culture" itself, is so alienating to Lenny (who confuses this notion of culture with the high culture of a "School for the Fine and Performing Arts") that she cannot accept his claims of love for her. By the end, as Ice Candy Man sits on the roadside with a broken arm, Lenny cannot sustain her contempt for him; however, one could ask if she is still simply naïve when she assumes that his reluctance to face her is due more to "internal demons than by fear of Mother's threats." Rather than forgiveness, Lenny seems to be resolved to let go of his crimes through her "pity" for him and accepts his "wisdom" on "the wayward ways of God and men and women." She realizes that "wisdom" is socially ordained and that the Ice Candy Man's self-justifications through the discourse of romantic love have a social power she cannot ignore. Her pity, then, is for the inability of this model of romantic love to have led to a different kind of history between Ayah and Ice Candy Man, a history that would have allowed them to form a union rather their necessary dissolution. Thus, she writes the history of 
Partition as a history of gender relations that despairs of the violence preventing them from achieving a resolution or true union. Ice Candy Man, the Muslim, ironically "disappears across the Waghah border into India," unable to resolve his desires either in the new state he had fought for or in the romantic love he used to justify his violence against Ayah.

The naïve perspective of Lenny matures, and with it comes a clearer consciousness of the gendered nature of the violence that has taken hold of the world around her. Yet, despite the ascendance of violence and the betrayal of the close ties between violence and certain seemingly neutral social ideals such as romantic love, Lenny's new knowledge allows her to comprehend and resolve the traumas of Partition. As Ambreen Hai has argued, this is not only a feature of the narrative itself but to some extent arises from the text's structure: "By constant parallels between the positioning and work of narrator and narrative, the text implies that its own work may be reconstitutive and salutary in revising national history and identity, or in working through collective trauma" (2000: 410). Thus, Ice Candy Man offers a counterhistory to the dominant national history of partition and, in addressing the centrality of an understanding of how violence is gendered, offers a space to "work through" the traumas of this experience in a way more effective than those of the nationalist narratives of this history.

\section{THE EYE OF THE MIRROR: WAR'S TRAUMAS AND TRANSGRESSIONS}

Liana Badr's novel 'Ayn al-Mirā (The Eye of the Mirror) ${ }^{11}$ narrates one of the Lebanese Civil War's early and formative traumas: the siege of a Palestinian refugee camp. The novel begins with the war's outbreak and continues up to the second year, when a siege developed at the Tal al-Za'atar Palestinian refugee camp, which was policed and defended by a Palestinian militia, the Fedayeen (sacrificers), a lightly armed group in the camp, aligned with the Palestine Liberation Organization (PLO). Phalangists - a militia dominated by Maronite Christians and inspired by a Spanish fascist party of the same name-laid siege to the camp for over a year, unable to break through the Fedayeen's defenses despite cutting off the camp from outside food and water supplies. During the siege, people in the camp lived under constant sniper fire, making it 
life-threatening to forage for food or water in the camp and the forests around it. The Phalangists eventually shelled the camp, leveling most of its buildings and driving its population into underground shelters for several weeks. Eventually, the PLO gave the Fedayeen the order to surrender and evacuate the refugees from the camp. In the days that followed, the Phalangists massacred large numbers of the male survivors of the camp and systematically raped women refugees as they evacuated via preordained "safe passages" from the camp. In all, some 4,000 refugees died in the siege and its aftermath, and the remaining 12,000 who survived were scattered to different locations throughout Lebanon. ${ }^{12}$

The Eye of the Mirror narrates the story of Aisha and her experiences as a refugee in the camp of Tal al-Za'atar before and during the siege; it follows a narrative strategy similar to that of Ice Candy Man by largely assuming the naïve perspective of a girl during an episode of acute social conflict. While Sidhwa's novel employs a first person voice to complicate the representation of partition violence, The Eye of the Mirror is in the omniscient third person and is panoptic in its representation of various characters in the camp. In addition to Aisha's family, the narrative follows the family of Hassan, who eventually marries Aisha. Despite this difference, it presents the narrative of Aisha in a highly internalized and similarly naïve perspective so as to undermine the identitarian polarizations the conflict generated. At moments, this perspective can be read in ways even more subversively than Cracking India, particularly in its uses of the experiences of war so as to imagine different social configurations than those available before war. In a sense, the text envisions liberatory possibilities through the traumas of war. ${ }^{13}$ At the beginning of The Eye of the Mirror, Aisha is a young girl employed as a servant by a convent school for wealthy Christian girls, outside Tal al-Za'atar. She is educated in exchange for her work, which places her in a position of some privilege in comparison to other girls of her social background. Within the camp, her family is one of the poorest, and so her work at the convent school offers her the rare possibility of social mobility. While her family is Muslim, she easily identifies with the Christian rituals in the school, and views the convent's nuns as her guardians, even more so than her parents. At one point she prays to herself, "Sister Mary. If only. If only she had been her family and spared her all this suffering" (14). In the school, she goes so far as to secretly 
pray at the church, disguising herself with a veil.

I beseech you, Oh Christ. She would contemplate him with exuberance, the pale-skinned handsome young man with the sad expression... I beseech you, Oh Christ. All these women pray to you. They play the organ and make supplications to you, kneeling on the cold white marble tiles, but you remain unmoved. It is as though you could not see the sad Virgin as she shifts her gaze from the ceiling to the women. Sometimes the Virgin would be unable to hold back the sadness in her heart, and her tears would turn into drops of olive oil on the cheeks of her icon. Once, her gaze met Aisha's in a trance of hymns, and the girl shivered, her eyes filling with tears of sadness for the holy woman who had suffered so greatly. Our Lady Mary (8).

In Aisha's imagination, the subtly gendered nature of the relations of Christ and Mary to the praying women presents a sacral trinity that eroticizes the Son and finds solace in the Mother. However, the Son is forever distant, "unmoved" to the women's prayers. The Mother mitigates this distance and allows for the girl's identification. This identification with the sacred is replicated in Aisha's later romantic desires and social relations. This cross-religious identification, while being class-inflected,${ }^{14}$ places Aisha on the margins of her community after a Christian militia attacks and kills a bus of Palestinian refugees. In the tensions that ensue, Aisha is sent home to her family, but she is uneasy about the religious rhetoric with which her family discusses the bus attack: "It's as though everyone was conniving against her. It's as though she and the nuns were responsible for the bus incident" (10). As outside tensions escalate and lead to the siege of the camp, Aisha finds herself silenced and imprisoned in a community from which she feels largely alienated.

This alienation is also largely a result of her discontent with the expected gender roles imposed upon her in the camp and by her family. The shock of finding herself dependent again on her family and under the eye of her unemployed and often-inebriated father, Asseyed, plunges her into an introspective silence. Humiliated by his inability to work, Asseyed vents his rage on his wife and children, beating them from time to time. Of course, the existential limbo of refugee life also factors largely into his violence, and he is constantly nostalgic about his family's previously respectable status in the Palestinian village the Zionist 
militias expelled them from in 1948. Thus the domestic violence in the refugee camp is situated within the larger context of violence that has dispossessed the Palestinians of their homeland. ${ }^{15}$

The naïve perspective here works in a different manner than in Ice Candy Man. In that text, Lenny matures through the violence, her marginality in a sense protecting her from its dangers. Her naïve perspective is, in a sense, a mark of her privilege. As a middle-class girl and member of a religious community not directly implicated by the violence, Lenny is less directly affected by the violence than some of those around her (e.g., Ayah or her Muslim servants). In The Eye of the Mirror, while Aisha begins with a similarly naïve perspective, due to her class status and religious identity, she is threatened directly by the violence. Her detached and semifantastic world, while in a pathological sense a coping mechanism, is a way to attempt to preserve her naïve vision of the world.

Yet the effectiveness of this tactic is limited. Having lost her previous sense of purpose and bereft of any optimism for her future, Aisha retreats more and more into herself and her imagination, rejecting the social realities around her, even to the point of ignoring the siege as it escalates. She does little more than carry out the simple chores she is assigned and refuses to socialize with her family or friends. It is not until her mother, Um Jalal, begins to act as an intermediary for the marriage proposal of a Fedayeen leader, George, that she begins to be conscious of her surroundings again. Aisha becomes infatuated with George, who is without a family and thus requires Um Jalal's services in matchmaking. In one meeting with the family, George is interrogated by Aisha's little sister, who asks George if he is Muslim or Christian, as his name is common for Christians and rare for Muslims. He laughs off the question, saying that George is a nom de guerre. Embarrassed, Um Jalal interjects that some of the Fedayeen are Christian Palestinians, and George adds that "Christ himself was a Palestinian" (46). The ambiguity about George's name and religion further fuels Aisha's romantic interests. These ambiguities also desacralize the conflict, as Asseyed, prone to anti-Christian outbursts, has to agree that the Phalangists are not representative of Christians as a whole. Furthermore, George acts largely as a Christ-figure for Aisha, distant and unmoved by her increasing love for him. Frustrated as she is by this, she accepts it as she accepted the futility of her fantasies about Christ. 
The conflation of the Christian Palestinians with the community's Muslim majority is one effect of the rhetoric that paints the conflict as being essentially religious. In a side story about Asseyed's friendship with a local Christian bar-keeper, Khwaja, the dissolution of relations between the Christian Lebanese and the Palestinians is transformed into a conflict of religions. The story suggests that the religious divisions between the communities result from and are not the cause of the conflict. Although the two men have known each other for years, their friendship begins to unravel just as the siege begins. Khwaja, who has benefited largely from his Palestinian clientele, begins to parrot the anti-Palestinian rhetoric of the Phalangists in arguments with Asseyed. When he hears this, Asseyed decides "with a painful sharpness that Khwaja belonged to a different race, remote and strange, unaware of the humiliation people were experiencing" (41). Eventually, he feels "compelled to destroy the trappings of the old friendship" (42). The destruction of the friendship happens so quickly that Asseyed must rationalize its cause as being essentially religious while not contextualizing the division within the larger political struggles leading to the siege in the first place.

When Aisha is forced into an arranged marriage with George's comrade, Hassan, George's marriage is indefinitely postponed when the father of his fiancée is kidnapped by the Phalangist militia. Aisha has no love for Hassan, but her new position as bride and mother-to-be is a certain liberation from her previous situation. Despite her horror at having to consummate her marriage with Hassan, she begins to warm to her new domestic situation within a largely feminized space. Her mother-in-law treats her respectfully, mostly out of her anticipation for a grandchild, and Hassan's father is a nearly senile old man who sits quietly in a corner for most of his waking hours. As Hassan himself is drawn to the front lines for days on end, Aisha finds herself more at ease in this new environment with Um Hassan and Hassan's sisters. However, her privilege in the house is based solely on the expectation that she is or will become pregnant. When Aisha experiences symptoms of what might be morning sickness, a guessing game ensues about the possibility of her being pregnant, an ambiguity sustained through the remainder of the narrative.

The question of Aisha's pregnancy metaphorizes her inability to integrate into the social fabric of the camp. She has tried to reject the 
marriage ordained upon her and kept herself from the activities associated with resisting the siege. Her motivation is clearly to rebel against the roles she is expected to accept, as a girl who is suddenly transformed into a woman and a person with an ambivalent sense of religious identity who is expected to follow the anti-Christian rhetoric with which the siege has resulted. However, her antisocial attitude leads Hassan's sisters to see her as nothing more than a selfish brat. In the context of the violence around them, they have no interest in Aisha's self-centered complaints and are unwilling to empathize with the trauma she has faced both in her marriage to Hassan (the violent consummation of their marriage, his distance from her, and his inability to relate to her) as well as to her losses after the siege, namely her education and her relatively independent life at the convent. In a sense, the loss and trauma she feels from these events seem frivolous in context to the other women of the war.

The subversive potential of imagining the war to be a space of upheaval wherein social transformations may occur is a consistent subtext within The Eye of the Mirror. As most of the men in the camp are sent to the front lines, the women of the camp assume the responsibility of maintaining and organizing the social space of the inner areas of the camp and the shelters, which become the only areas safe from the constant shelling. In this intensely feminized space, the women excel at their new roles. Hassan's polio-stricken sister cares for the war-wounded at the medical center and falls in love with a Lebanese male nurse. Hana, George's fiancée, gains fame in the camp as the signal (ham radio) operator. Umm Hassan becomes a full-time baker, feeding both the Fedayeen and the less fortunate of the camp with her lentil bread.

Eventually, Aisha's flights of imagination seem to intervene in the material surroundings of the camp. When Aisha follows her younger siblings along a secret path they have discovered, they are led to an abandoned candy factory. Inside, they find huge mountains of the various sweets left behind, bizarre delicacies given the austere diets the refugees have been forced to endure while under siege. In the factory, Aisha also discovers a pocket mirror, seeing herself for the first time in ages. Her younger brother grabs the mirror, warning her that snipers may catch a glimpse of the reflection. The discovery of the mirror is jarring, as its gaze localizes her within the environment she has so 
far been denying. The mirror is the simplest medium of representation available to her and presents the first opportunity for her to comprehend a representation of herself, but it is also a dangerous medium, as it attracts the attention of those who wish Aisha and the other Palestinian refugees dead. The mirror image, as both a signification of herself and a glimmer that may attract snipers, also produces another disjunction: it identifies Aisha as distinct within her own community. Through her representation, Aisha experiences her essential difference, deepening the discontinuity between herself and her community. This dual nature of the mirror symbolizes the conflict Aisha has experienced both within herself and the world around her; as her identity comes to be more and more delimited, she becomes implicated within the surrounding conflict.

From the candy factory, the group goes to an abandoned church next to the school housing the Phalangist headquarters. Standing outside the church, Aisha recalls how as a child she used to imagine the taste of the wine and bread of communion and how she had gone to a wedding at a church, only to be shunned by a woman there after admitting she was Palestinian. This introspective space is intruded upon by a militiaman who discovers the group. He shoos them off, sparing their lives by choosing not to shoot them on sight. Later, as the shelling intensifies, Aisha sleeps for hours and dreams.

The shelling increased day by day and she slept and slept as though the echoing of cannons were a soporific injection to which she had become addicted. She would slide beneath the quilt and dream. Songs rise over the shining marble altar. She is still a child, running barefoot on the cold stairs. The damask roses. They are red, pink and white. Each is as big as the palm of a hand. The church is all golden. Hymns inside. The roses on the fence. The roses! They would dress the girl in white. The boy would wear a long brown gown with a black belt. Like saints. The girl. The clothes of the Virgin Mary. Then Aisha! Forbidden. The nun says: "You want to watch, look from outside" (142).

These dreams and others operate as moments in which Aisha can imagine a world outside the siege of the camp and a reality other than war. However, after the trip to the church, Aisha's dreams and memories begin to emphasize her limitations in participating in the Christian 
rituals with which she so clearly identifies. While these dreams open an imaginary potential for a life outside the camp, Aisha's imagination becomes more localized within her own context, which breaks her out of her self-pity. The mirror acts as a way for her to finally see herself and thus to finally come to terms with her position in the camp. Rather than accept this fate, Aisha slowly begins to act within her social sphere, looking for ways to take action within her living conditions.

The process linking the visions of her dreams to a more active engagement with the world-and the war-around her marks another critical approach to women's conventional roles in war narratives. As Carol Acton has suggested, women generally have operated within these texts as the locus for a feminine gaze upon the traumas of the war. Acton explains that with this gaze "the woman's role as nurse to the injured men occasions her traumatic seeing and draws attention to the role of vision as a gendered activity...women writers also claim to see and know war through a specifically female gaze" $(2004: 54,56)$. Vision, for Aisha, does not function as part of the gendered gaze described by Acton. In fact, Aisha is most often described in the text as almost unable to see or observe the social realities surrounding her, at least until the mirror metaphor. Aisha's subversion-and the mark of her rebellion against her social role as a woman - is her retention of a naïve perspective against the pressures to accept and adopt maturity and become a grown woman. Through this, she seeks a new role. The mirror, rather than reflecting the feminized gaze upon the trauma of war, reflects Aisha herself, transforming the war narrative into a narrative of selfidentification and self-visualization.

The naïve perspective, and the developmental narrative of maturation that emerges from it, takes on a more precise focus when Hassan is killed in combat while attempting to save a comrade trapped inside the church. The overlap of church as the serene locale for Aisha's peace of heart and as a battlefield and site of the death of Hassan raises contradictions in the employment of the sacred space. If the church is an imaginary escape for Aisha, it is still a deadly place for the Fedayeen, just as it physically protects the Phalangists as they continue to attack the camp. The death of Hassan throws the outer dimensions of Aisha's world into turmoil, but she hardly acknowledges it. Instead, caught inside a bomb shelter, she helps a young Lebanese woman married to a 
Palestinian fedayoun give birth to a child and helps her care for it. While still distant from her family and surroundings, Aisha begins to socialize by assisting the young woman, Georgette, with her baby boy. There is, no doubt, a mirroring in references to St. George (the patron saint most revered by Arab Christians) and the presence of the two characters by the name of George and Georgette in Aisha's surroundings; one may see the appearance of the latter as rekindling Aisha's earlier "infatuation" with the former. ${ }^{16}$ Dehydrated and weak, Georgette is unable to nurse the child, who dies, which affects Aisha far more than the death of Hassan. Somehow, watching the torturous death of Georgette's child and Georgette's ensuing madness brings Aisha closer to finding her own place within the struggle to resist the siege.

As the Fedayeen are finally forced to retreat from the camp, attempting to navigate the forests and fields around the camp to an area outside the control of the Phalangists, the camp inhabitants are left to march from the camp and surrender themselves to an uncertain fate. The narrative splits its focus to George and a group of his comrades as they attempt to cross over to PLO-controlled territory, and Aisha and her family as they are marched from the camp and witness the Phalangists randomly killing men and boys and taking away women in their trucks. This split in the narrative, along gender lines, reads the outcome of the siege as being experientially different for the men and the women. During the march, Aisha suddenly and for the first time finds herself wondering why this conflict has occurred. "The only thing that mattered to her now was understanding why all that had happened. Why are we here? Why death? Why don't we live normally like other people? Why don't they leave us alone?" (260) Her anger about this fate, which had not previously been clear to her, is a step on her emergence from self-pity. Rather than focusing on the events leading to her personal anguish-leaving the convent school, being forced into marriage-escaping the camp causes her to reevaluate her position. As she arrives at the refugees' final destination, an old museum on the lines between the Christian and Muslim forces, she looks at the Roman-columned edifice and identifies it with the Roman persecution of the early Christians. "Why do they do this to us? If it is because they are yearning for Roman glories, are we the Christians to be savaged by lions in the arena?" (260) The museum, a symbol of the retention of the region's history, becomes 
a vessel to further undermine the hard identitarian lines the conflict has drawn and to imaginatively appropriate the legacy of early Christianity as being equal to that of the Palestinians. Through an understanding of this history-or through the assertion of an alternative to it-Aisha's perspective, once naïve, is fully transformed.

As she looks at the families gathered, now almost entirely comprised of women, she thinks of something Um Hassan had told her. "My child, we shall all become strong women. Have they left us any other choice? They take everything away from us. Marriage, children, homes, stories, old people. . everything. So, all the time we defend ourselves as though we were not women, but standing in trenches" (260). This statement, that war has taken from women the ability to be "women," undoes a possibility of gendered narrative of the struggle, the idea that the war story must represent wars as waged by men. The women are no longer "women," and this consequence has a liberating potential. Much of what was lost in siege is for Aisha aspects of the patriarchal nature of the gender roles she had been rebelling against, e.g., marriage, children, home, etc. But rather than simply escaping these roles, she resolves to go forward independently while not ignoring the struggles of her community. Choosing in the end that she is pregnant after all, she resolves to accept her role as a mother-to-be: "Staring at her mother with unaccustomed boldness, she said: 'That is my responsibility... I don't want anyone else to take it instead of me" (264). The "unaccustomed boldness" of these final words from Aisha marks the dissolution of her self-pity and enables her to imagine the potential for a transformed community with herself in a new role. The trauma of war, as narrated through the developmental narrative of a naïve perspective, results in a liberating potential for Aisha to rethink her relationship to her world and accept the challenge of changing it.

\section{THE NAÏVE PERSPECTIVE AND WOMEN'S COUNTERHISTORIES TO THE WAR STORY}

Women have much less at stake in distorting their messy experiences into the neat, tidied-up War Story mold. Their stories contest the blind acceptance of a dyadically structured world and make a mockery of such notions as Defender and Defended.... The breakdown of those 
binaries then allows us to see the cracks in others such as victory versus defeat, fact versus fiction, action versus writing, experience versus recording, war versus peace....These binaries, these women seem to say, were never real (cooke 1991:295).

In this paper, I have compared two novels coming from two very different histories and backgrounds. While this is a productively problematic move in that it may seem to be an effort to equate very specific experiences best understood in the context of their locales, it is nonetheless important to draw some larger conclusions from the juxtaposition of these narratives to see how they may present a general critique of what cooke calls "masculinity-enforcing" war stories. On one hand, Badr's novel follows a fundamental shift in intent in Palestinian literature in general. The Eye of the Mirror is a narrative largely outside of the classical models of nationalist narratives. As Amal Amireh argues, "Generally speaking, the Palestinian literary national narrative is erotic and male. In it, as is the case in other nationalist narratives, Palestine is metaphorized as a woman" (2003:750). Liana Badr's work, such as The Eye of the Mirror, "seeks to feminize the fertility metaphor by shifting emphasis away from the men to the women" (756). While it concerns the tragic experiences of the displacement and destruction of Palestinian society, it does so in a way divorced from the nationalist narratives that have come to define post-1948 Palestinian literature. ${ }^{17}$

Sidhwa's Cracking India undoes the nationalist orientations of narratives on Partition, using remarkably comparable tactics of perspective and position. In Ambreen Hai's words, it is an example of "border writing," because "by refracting national history through a gendered consciousness, Sidhwa shifts the historiographic perspective to those not usually regarded as central to that history" (2000:389). While gender plays an important role in this repositioning, it is nonetheless the case that as authors, women have played important roles in nationalist literatures as well; there are notable women authors who can well represent the nationalist Palestinian discourse to which I have referred..$^{18}$

This is not to undermine the historical context that produced these nationalist narratives but rather to suggest that feminist counterhistories of these kinds can fill important gaps in the understanding of these histories. Through the employment of a naïve perspective, these works rep- 
resent the histories of these events in ways that challenge the prevalent narration of political histories and in doing so problematize the vulgar gendering common to war narratives. Through these two texts, we may begin to outline the possible applications of such "literary" writing to expand our understanding of what "history" may be, by finding modes of historical representation that highlight experiences not traditionally accounted for in nationalist historiographies. Cracking India draws a gendered view of the precipitation of and outcomes from the implementation of Partition, narrating the costs of this political and ideological process on women. The traumas of the conflict are, as with The Eye of the Mirror, cast within a narrative that follows the maturing perceptions of an initially naïve protagonist in order to highlight the arbitrary and socially constructed identities outlining the binaries of the conflict. The Eye of the Mirror presents the costs of the realization of the violence of these binaries in more intimate and stark terms by profoundly marking these costs on the body of Aisha. Her fate is more uncertain and more tragic than that of Lenny, as in Cracking India, Ayah bears the costs of Partition. In this difference, a comparison of these texts also brings to bear the question of how class also compounds a gendered perspective. Yet The Eye of the Mirror ends on a paradoxically more triumphant note than Cracking India; by surviving the terrors of the siege, Aisha is portrayed as more significantly mastering her destiny, even as she willfully accepts/determines her own pregnancy. Lenny, while escaping the worst of Partition, enters the postcolonial world much more pessimistically, much less certain of her position within it. Despite these different ends, both texts cast women's experiences of these conflicts as central to an assessment of the outcome of each conflict. They do so by affirming that women's accounts of war can undo the binaries often presumed in these events by predominant war narratives or prevailing political histories and their rationalization of the violence of war.

\section{ACKNOWLEDGMENTS}

I wish to thank the anonymous reviewers of this essay for their constructive comments, as well as those of the editors of JMEWS. Gauri Viswanathan also provided very insightful comments on an earlier version of this paper, for which I am very grateful. 


\section{NOTES}

1. While this study makes use of a number of terms common in the field of trauma studies, it will not be possible to go deeply into the analysis of the texts in question within the framework of concepts such as social memory, closure, or trauma. However, references to these concepts will occasionally appear in this article. For more on the application of trauma studies to literary study, see Dominick LaCapra, Representing the Holocaust: History, Theory, Trauma (Ithaca: Cornell University Press), 1996; Cathy Caruth, Unclaimed Experience: Trauma, Narrative, and History (Baltimore: Johns Hopkins University Press), 1995; and Kali Tal, Worlds of Hurt: Reading the Literatures of Trauma (Cambridge: Cambridge University Press), 1995.

2. Although I have chosen to use the original title of Cracking India in this article, all references to the text are from Bapsi Sidhwa, Ice Candy Man (London: Penguin Books, Ltd), 1989. Cracking India/Ice Candy Man has been made into a major feature film, Earth, directed by Deepa Mehta (1998).

3. As miriam cooke has argued, "[p]ostcolonial wars have transformed the relationship between women's participation in war and its narration. Women are inscribing their experiences in war into the war story. They are thus countering others' naming of women's experiences as having not been in war." "Arab Women, Arab Wars," Cultural Critique 29 (Winter 1994-5):25.

4. In this article, the term "naïve perspective" is to some extent derived from Zachary Baiterman's discussion of the tensions between "naïve reference" and the sublime in narratives on the traumas of the Holocaust. Baiterman argues that naive aesthetics-derived from "children and lost childhood"-present an alternative to the dangers of the over-aestheticization of the Holocaust through what he terms the "Holocaust-Sublime." Here, the use of naïve intends a dual meaning, not only referring to the childlike in the perspectives of young characters but to the manner in which these texts refuse to make sublime the traumas of partitions and war. Zachary Baiterman, "Against Holocaust-Sublime: Naive Reference and the Generation of Memory," History \& Memory 12(2):7-28.

5. Despite many points of comparison, the Palestinian Nakba and the Partition of India have rarely been the feature of a comparative study nor has the Lebanese Civil War. The intention behind this study is a provocative assessment of the histories of these events through a comparative framework but not denying the specificity of each of them.

6. There is a significant body of literature by political and social scientists on the principle of political partitions. For a somewhat critical assessment of political theory on partition, see Nicholas Sambanis, "Partition as a Solution to Ethnic War: An Empirical Critique of the Theoretical Literature," World Politics 52(4):437-83. For a defense of partition policies, see Chaim D. Kaufmann, "When All Else Fails: Ethnic Population Transfers and Partitions in the Twentieth Century," International Security 23(2):120-56.

7. This statement raises the question of literature as an act of witnessing, a question that cannot be adequately attended to in this context. However, coun- 
ternarratives such as those advocated by Menon and Bhasin are very often closely related to autobiography. Both Sidhwa and Badr have related that their writing of these books was motivated by their personal experiences during the historical events they recount.

8. Perhaps no work has more significantly signaled the move to apply literary methodologies to history than Hayden White's Metahistory: The Historical Imagination in Nineteenth-Century Europe (Baltimore: Johns Hopkins University Press), 1973. Accordingly, literature has come to be more often brought into historical investigation as well. See David Prochaska, "History as Literature, Literature as History: Cayagous of Algeria," American Historical Review (Dec. 1996).

9. For more on Liana Badr's life and an overview of her writing, see Therese Saliba, "A Country Beyond Reach: Liana Badr's Writings of the Palestinian Diaspora," in Lisa Suhair Majaj et al., eds., Intersections: Gender, Nation, and Community in Arab Women's Novels (Syracuse: Syracuse University Press), 2002, pp. 132-62.

10. The classical poetry he recites follows a popular formula of presenting the voice of a self-subjugated lover seeking annihilation in his quest for the beloved. While offering a model of masculinity that diverges from love narratives celebrating masculine power and dominance, the inversion of the power dynamic in this classical poetry nonetheless centers on limited and highly inflexible gender roles.

11. Liana Badr, 'Ayn al-Mir'ā (Casablanca: Dar Tubqal lil-Nashr), 1991. References in this article are to the English translation, The Eye of the Mirror, translator Samira Kawar (London: Garnet Pub. Ltd), 1991. In addition to being a novelist, Badr controversially took a position with the Palestinian Authority in the Ministry of Culture, during the Oslo period. She has since resigned her post and moved into filmmaking and screenwriting, where her most noteworthy achievement is writing the screenplay for al-Quds fi Yawm Akhar (released in English as Rana's Wedding), by the Palestinian director Hany Abu Assad (2003).

12. For a succinct history of these events, see David Gilmour, Lebanon: The Fractured Country (London: Sphere), 1987; and Robert Fisk, Pity the Nation: Lebanon at War (London: Oxford Paperbacks), 2001.

13. This conclusion can be drawn from a number of other texts dealing with the Lebanese Civil War, texts that interestingly also presume a largely naïve perspective, such as Hanan al-Shaykh's Hikayat Zahra (The Story of Zahra) or Jocelyn Saab's film Ghazl al-Binat (released as Suspended Life). In both of these narratives, an adolescent girl arguably comes to find that the traumas of war and sexual awakening liberate her from previous limitations or social restrictions.

14. The class dynamic of Aisha's affiliations with Christianity is due to the fact that in and around the camp, Lebanese Christian merchants represent the upper classes to the predominantly Muslim refugees. In the convent school, the boarders are described as the daughters of influential or wealthy families.

15. Amal Amireh describes this tendency in Palestinian nationalist discourse as centering on a masculine "loss of virility," which "signifies the loss of Palestine as loss of female virginity but also of male virility, since the virile actor now is the rapist/enemy. This male loss of virility is inscribed as Palestinian defeat." "Between Complicity and Subversion: Body Politics in Palestinian 
National Narrative," The South Atlantic Quarterly 102(4):747-72.

16. On this same topic, it is worthwhile to note that Aisha is the name of the favorite wife of the prophet Muhammad, who also assumed a significant role of political and military leadership after his death. With both George and Aisha, however, Badr is using names with heavy religious significance for characters who are religiously ambiguous or ambivalent.

17. For examples in English translation, see Salma Jayyusi, ed., Anthology of Modern Palestinian Literature (New York: Columbia University Press), 1992.

18. As Amal Amireh has noted, "[in Palestinian literature], not surprisingly, we find in the work of both male and female writers a reproduction of the dominant gendered national narrative." South Atlantic Quarterly 102(4):749-50.

\section{REFERENCES}

Acton, Carol

2004 Diverting the Gaze: The Unseen Text in Women's War Writing. College Literature 31(2):53-79.

Amireh, Amal

2003 Between Complicity and Subversion: Body Politics in Palestinian National Narrative. The South Atlantic Quarterly 102(4):747-72.

Badr, Liana

1991 'Ayn al-Mir’ā, Casablanca: Dar Tubqal lil-Nashr.

1991a The Eye of the Mirror. Translated by Samira Kawar. London: Garnet

Pub. Ltd

Baiterman, Zachary

2000 Against Holocaust-Sublime: Naive Reference and the Generation of

Memory. History \& Memory 12(2):7-28.

cooke, miriam

1991 Women and the War Story. Raleigh: Duke Press.

1994 Arab Women, Arab Wars. Cultural Critique (29):5-29.

Hai, Ambreen

2000 Border Work, Border Trouble: Postcolonial Feminism and the Ayah

in Bapsi Sidhwa's Cracking India. Modern Fiction Studies 46(2):379-426.

LaCapra, Dominick

1995 History, Language and Reading: Waiting for Crillon. American Historical Review 100(3):799-828.

Majaj, Lisa Suhair, Paula W. Sunderman, and Therese Saliba, eds.

2002 Intersections: Gender, Nation, and Community in Arab Women's

Novels. Syracuse: Syracuse University Press. 
Menon, Ritu and Kamla Bhasin

1998 Borders and Boundaries. New Brunswick, NJ: Rutgers University Press.

Sambanis, Nicholas

2000 Partition as a Solution to Ethnic War: An Empirical Critique of the Theoretical Literature. World Politics 52(4):437-83.

Sidhwa, Bapsi

1989 Ice Candy Man. London: Penguin Books.

Sidhwa, Bapsi and Preeti Singh

1998 My Place in the World. Alif: Journal of Comparative Poetics (18):290-8. 